Pol. J. Food Nutr. Sci., 2019, Vol. 69, No. 3, pp. 289-296 DOI: $10.31883 /$ pjfns/110564 http://journal.pan.olsztyn.pl

Original research article

Section: Food Technology

\title{
Effects of Biopreservatives Combined with Modified Atmosphere Packaging on the Quality of Apples and Tomatoes
}

\author{
Olga Babich ${ }^{1,2}$, Lyubov Dyshlyuk ${ }^{3}$, Stanislav Sukhikh ${ }^{2}$, Alexander Prosekov ${ }^{1}$, \\ Svetlana Ivanova ${ }^{3,4 *}$, Valery Pavsky ${ }^{3,4}$, Tatiana Chaplygina ${ }^{3,4}$, Olga Kriger $^{2}$ \\ ${ }^{1}$ Laboratory of Biocatalysis, Kemerovo State University, Krasnaya Street 6, Kemerovo, 650043, Russia \\ ${ }_{2}^{2}$ Institute of Living Systems, Immanuel Kant Baltic Federal University, A. Nevskogo Street 14, Kaliningrad, 236016, Russia \\ ${ }^{3}$ Research Institute of Biotechnology, Kemerovo State University, Krasnaya Street 6, Kemerovo, 650043, Russia \\ ${ }^{4}$ Department of General Mathematics and Informatics, Kemerovo State University, \\ Krasnaya Street, 6, Kemerovo 650043, Russia
}

Key words: bacteriocin-like substances, biopreservative, comprehensive storage, fresh fruit and vegetables, MAP

During the cultivation and harvesting of fruit and vegetables, a large number of microorganisms accumulate on their surface. Their active and excessive reproduction leads to spoilage of products. The purpose of the study was to assess the effect of combining various packaging technologies with different biopreservatives on the stability of physicochemical and microbiological characteristics of fresh vegetables and fruit during storage. Samples of fruit and vegetable products (apples, tomatoes) were subjected to the following procedures: packaging without treatment, treatment with a mixture of bacteriocin-like substances and packaging with or without modified atmosphere. Packaged samples were stored in a refrigerator at a temperature of $4^{\circ} \mathrm{C}$ for 25 days. The bacteriocin-like substances in combination with modified atmosphere reduced the contamination of samples by pathogenic microorganisms at least 4 times while maintaining the quality characteristics of the fruit during the storage period. A biopreservative in combination with modified atmosphere can be used to control microbial spoilage and to keep fruit and vegetables fresh after harvest.

\section{INTRODUCTION}

Fruit and vegetables are the best sources of nutrients. They contain natural ingredients such as carbohydrates, proteins, organic acids, vitamins, etc. [Watson \& Preedy, 2016; Dyshlyuk et al., 2017]. Consumption of fruit and vegetables remains stable, despite their price increase. One of the reasons for the increase in production costs is waste (at least $20 \%$ of all fruit and vegetables produced spoil, not reaching the consumer) [FAO, 2011; De Laurentiis et al., 2018; Prosekov \& Ivanova, 2018]. In the process of maturing, harvesting, transporting, and storing, the fresh vegetables and fruit remain unprotected from sources of contamination by pathogenic bacteria, spores of mold and fungi that remain active for a long time [Paskeviciute et al., 2018]. Economic losses are also caused by microorganisms (bacteria, fungi, mold) that colonize fruit surface [Buzby \& Hyman, 2012; Jaeger et al., 2018]. Appropriate post-harvest treatments can minimize moisture loss, slow the respiration rate and save fruit for the consumer. The technologies for preserving the qualitative characteristics of fresh fruit and vegetable products include, first of all, ensuring certain climatic conditions (temperature,

\footnotetext{
* Corresponding Author: Tel.: + 7 (3842) 58-12-26

E-mail: pavvm2000@mail.ru (S.A. Ivanova)
}

humidity, illumination), as well as washing, vacuum packaging, treatment with preservatives, irradiation with ultraviolet, use of a modified gas medium and their combination [Ma et al., 2017; Putnik et al., 2017].

The most promising is the complex use of modified atmosphere packaging with other technologies (temperature regime, biopreservation, UV irradiation, etc.), which determine a double barrier to the growth of microorganisms and ensure the safety and preservation of food products, including fresh fruit and vegetables [Allende \& Artés, 2003; Alvarez et al., 2015; Hussein et al., 2015; Oliveira et al., 2015].

The work performed by Wang et al. [2015] presents technology of preserving cherries in the process of long-distance sea transportation at a temperature of $0^{\circ} \mathrm{C}$. Colgecen \& Aday [2015] preserved cherries in modified atmosphere packaging (MAP) with a chlorine dioxide dissolver for 5 weeks without visible damage to the fruit by rot and mold at a temperature of $4^{\circ} \mathrm{C}$. Argyri et al. [2015] used packaging with modified gas medium for olives fermented with lactic acid bacteria; the probiotic characteristics of this product were retained within 6-month storage in refrigerator. There are enough studies that use bacteriocins of lactic acid bacteria or bacteriocin-like inhibitory substances (BLIS) produced by Bacillus cereus to preserve food products, including fruit and vegetable products [Settanni \& Corsetti, 2008; Leroi et al., 2015; 
Leite et al., 2016; Cavicchioli et al., 2017; Ho et al., 2018]. The search for producers of bacteriocins of a broad spectrum of action and safe for humans is being continued [Nes et al., 2006; Molloy et al., 2011; Burke et al., 2013; O'Bryan et al., 2015]. However, there are no works in free access with the results of the joint use of biopreservatives and MAP.

In the present study, the effect of bacteriocin-like substances, a consortium of bacteria from the surface of fruit and vegetable products, in combination with various packaging technologies on the stability of the physicochemical and microbiological characteristics of fresh vegetables and fruit has been assessed under conditions simulating commercial use during storage at various temperatures.

\section{MATERIALS AND METHODS}

\section{Materials and chemicals}

Fresh ripe red tomatoes of Alcazar cultivar and yellow apples of Golden cultivar were purchased in the retail networks of the city of Kemerovo (Russian Federation) in August 2017. Fruit of medium size (apples $180 \pm 10 \mathrm{~g}$, tomatoes $150 \pm 10 \mathrm{~g}$ ) with no visible damage were selected.

Food gases (carbon dioxide $\mathrm{CO}_{2}$, oxygen $\mathrm{O}_{2}$, nitrogen $\mathrm{N}_{2}$ ) were purchased from Linde Gas (St. Petersburg, Russia). The study used acetic acid and boric acid (LLC ComponentReactiv, Russia); hydrochloric acid, sodium acetate (LLC Component-Reactiv, Russia); isopropanol (LLC Plant Chemisol, Russia) and all other chemicals of analytical or higher grade.

\section{Bacteriocin preparation}

Cultures of microorganisms (Bacillus pumilus, Bacillus safensis) were isolated from fruit and vegetables [Zimina et al., 2016]. Triturated fruit were placed into a liquid nutrient broth medium (meat-peptone broth) and cultivated at $30 \pm 2^{\circ} \mathrm{C}, 37 \pm 2^{\circ} \mathrm{C}$ and $45 \pm 2^{\circ} \mathrm{C}$ for $1-5$ days. When sufficient biomass was grown, inoculation was performed onto nutrient agar (meat-peptone agar) daily until separate colonies were formed. Genetic analysis of the strains was performed for identification via $16 \mathrm{~S}$ RNA sequencing using the Sagner Method with "ABI Prism Big Dye Terminator Cycle Ready Reaction Kits Sequencing" (Appliedbiosistems, USA) and GSJunior 454 sequencer (Roche, Switzerland). Isolated microorganisms were stored in a freeze-dried state in ampoules at a temperature of $4 \pm 2^{\circ} \mathrm{C}$ for at least 24 months.

Lyophilized cultures of the isolated microorganisms were reconstituted by transferring the contents of ampoules to tubes containing sterile skimmed milk. Cultures were incubated at $37^{\circ} \mathrm{C} .5 .0 \%$ inoculum was added to MRS-broth and incubated at a temperature of $37^{\circ} \mathrm{C}$ for $16 \mathrm{~h}$ until the concentration of microorganisms reached $1.5 \times 10^{6} \mathrm{CFU} / \mathrm{mL}$.

At the end of the cultivation, the biomass was separated from the nutrient medium by centrifugation at $8000 \times g$ for $20 \mathrm{~min}$. Then, the supernatant was concentrated on hollow fibers which cut off substances with a molecular mass of more than $15 \mathrm{kDa}$; stirred with dry sodium chloride $(0.5 \mathrm{M})$ at a stirring speed of $100 \mathrm{q} / \mathrm{min}$ for $20 \mathrm{~min}$; centrifuged at $10,000 \times g$ for $15 \mathrm{~min}$. Water was added to the precipitate at a volume of $0.1 \%$ of the supernatant washed with isopropyl alcohol ( $0.1 \%$ of the supernatant) for $30 \mathrm{~min}$ at a temperature of $0^{\circ} \mathrm{C}$.

Evaporation of isopropanol was carried out with a rotary evaporator at a temperature of $60^{\circ} \mathrm{C}$. The solution with water and activated carbon $(0.5 \% \mathrm{w} / \mathrm{v})$ was kept for $15 \mathrm{~min}$, centrifuged at $10,000 \times g$ for $15 \mathrm{~min}$; filtered through a membrane that cuts off molecules with a molecular weight of more than $10 \mathrm{kDa}$. Lyophilization of the obtained biopreservative compounds was carried out with the following parameters: duration $90 \mathrm{~min}$, drying temperature $30^{\circ} \mathrm{C}$, drying duration $6 \mathrm{~h}$, drying layer thickness $2 \mathrm{~mm}$.

\section{Sample preparation}

Apple and tomato fruit were stored at $4{ }^{\circ} \mathrm{C}$ and at atmospheric pressure after purchase. Fresh fruit were washed with tap water, dried at room temperature and immersed in a $1 \%$ solution of biopreservative for $1 \mathrm{~min}$. Each fruit was considered as an experimental unit and, after treatment with bacteriocin, was placed in a sealed packet with modified atmosphere. Three different combinations of fruit treatments were examined: in a package without treatment (control), in a package with biopreservative treatment (BIO), and in a package with a modified gas medium and with biopreservative treatment (BIO+MAP). In total, 288 fruit (144 apples and 144 tomatoes) were packed for each treatment method. The treated samples were stored at $4^{\circ} \mathrm{C}$ for 25 days. Sampling for microbiological analyses was performed on day $0,5,10,15,20$, and 25 for measurements of the basic microbiological parameters (pathogenic bacteria and fungi growth), whereas sampling for the evaluation of quality indicators during storage was done on day 0 and 25. Sampling on day 0 was performed $2 \mathrm{~h}$ after packaging. Samples were aseptically removed from the package.

\section{Packaging technologies}

Fresh fruit were sorted at room temperature and packaged aseptically into $10 \times 10 \mathrm{~cm}$ polypropylene bags $(0.025 \mathrm{~mm}$ thickness) under the following conditions: MAP1 $-3 \% \mathrm{O}_{2}$ $+95 \% \mathrm{~N}_{2}+2 \% \mathrm{CO}_{2}$ (apples); MAP2 - 3\% $\mathrm{O}_{2}+77 \% \mathrm{~N}_{2}$ $+20 \% \mathrm{CO}_{2}$ (tomatoes). Bags containing fruit were sealed and checked for punctures or tightness of the seal by immersion into water.

\section{Microbiological analysis}

Washings from the surface of the fruit were done with a sterile cotton pad soaked in a peptone-salt solution (different parts of the fruit surface with a total area of $100 \mathrm{~cm}^{3}$ were wiped). The peptone-salt solution was prepared as follows: under slow heating. The pad was placed in a test tube with $10 \mathrm{~mL}$ of the peptone-salt solution $(8.5 \mathrm{~g}$ of sodium chloride and $1.0 \mathrm{~g}$ of peptone were dissolved in $1 \mathrm{~L}$ of distilled water with $\mathrm{pH} 7.0 \pm 0.1$ ). The contents of the test tube were mixed thoroughly. The resulting suspension was considered the initial dilution.

The washings from the surface of fruit were put on the agar surface (VRBL and SABOURAUD). The total number of microorganisms after the treatment of the fruit was determined by inoculating washings from the surface of the fruit 
on the agar in a Petri dish. Each Petri dish was filled with about $15 \mathrm{~mL}$ of $44-47^{\circ} \mathrm{C}$ VRBL-agar culture medium (Merck, Germany) to determine pathogenic microorganisms. After the medium in the Petri dishes had solidified, about $4 \mathrm{~mL}$ of $44-47^{\circ} \mathrm{C}$ used agar medium were poured to create a second layer. SABOURAUD-4\% dextrose agar (Merck, Germany) was used to determine the presence of fungi.

After solidification, the prepared dishes (upside down) were incubated at a temperature of $(37 \pm 1)^{\circ} \mathrm{C}$ for $(24 \pm 2) \mathrm{h}$ to detect pathogenic bacteria, and at a temperature of $(25 \pm 1)^{\circ} \mathrm{C}$ for 5 days to detect fungi (additionally, growth media were left at room temperature for 1 to 2 days). Regardless of the presence or absence of growth signs including blackening, inoculation with a smear loop was performed from the culture liquid on the surface of one of the agarized selective diagnostic mediums: Chromocult Coliform Agar ES (Merck, Germany), OXFORD agar (Merck, Germany), or PALCAM-agar (FBUN SSC PMB Obolensk, Russia). After incubation, Petri dishes with 15 to $150 \mathrm{CFU}$ of bacteria or yeast and 5 to $50 \mathrm{CFU}$ of fungi were selected and counted. The sensitivity limit for the bacterial number was about $10^{2} \mathrm{CFU} / \mathrm{mL}$.

Species of fungi present on the surface of the fruit was determined by molecular genetic analysis. The nucleotide sequence of $16 \mathrm{~S}$ RNA gene was determined through the $16 \mathrm{~S}$ RNA fragment sequencing using the Sanger method [Sanger et al., 1977].

\section{Quality analysis}

To calculate the average weight of fruit in grams, 30 tomatoes and 30 apples were weighed, respectively, on the electronic scales (BK 600.1, MASSA-K, Russia) with an accuracy of $0.001 \mathrm{~g}$.

Mass fraction of total soluble solids (TSS) was determined by placing $0.5 \mathrm{~mL}$ of a fruit homogenate, purified by centrifugation $(4000 \times g, 10 \mathrm{~min})$, on hand prism refractometer Atago PR1 (ATAGO CO., LTD, Tokyo, Japan), and the results are presented in ${ }^{\circ}$ Brix [Javanmardi \& Kubota, 2006].

Titratable acidity was determined by titration of $10 \mathrm{~mL}$ of fruit homogenate to a $\mathrm{pH}$ value of 7.6 using $0.1 \mathrm{M}$ sodium hydroxide and expressed in $\mathrm{g} / \mathrm{L}$ of citric acid; measurement was performed with a digital $\mathrm{pH}$-meter ( $\mathrm{pH}-150 \mathrm{M}$, Gomel'skiy Zavod Izmeritel'nykh Priborov, Russia).

The firmness of the fruit was evaluated by puncture strength $(\mathrm{N})$ test with a digital penetrometer PCE-PTR 200 (PCE Instruments UK Ltd, Hampshire, UK). Fruit were compressed with a constant speed of $0.95 \mathrm{~mm} / \mathrm{s}$, the diameter of the puncture was $5 \mathrm{~mm}$.

The color of vegetables was determined using Minolta Chroma Meter model CR-200B (Konica Minolta, Tokyo, Japan) at three different points located in the equatorial area [HunterLab, 2008]. The colorimeter has a beam diameter of $8 \mathrm{~mm}$, three response detectors set at 0 viewing angle and a CIE standard illuminant $\mathrm{C}$ with diffuse illumination. This illuminant is accepted as having a spectral radiant power distribution closest to reflected diffuse daylight. Color changes were documented throughout the experiment. $\mathrm{L}$ values indicate lightness (black $[\mathrm{L}=0]$ and white $[\mathrm{L}=$ 100]), a values indicate redness-greenness (red $[a=100]$ and green $[a=-100])$, b values indicate yellowness-blueness (yellow $[b=100]$ and blue $[b=-100])$. Chroma (C) $(C=$ $\sqrt{ }\left(a^{2}+b^{2}\right)$ measures color saturation or intensity and the hue angle $(h=1 / \tan (b / a))$ determines the red, yellow, green, blue, purple, or intermediate colors between adjacent pairs of these basic colors. A lower hue value indicates a redder product [Ayala-Silva et al., 2005].

\section{Statistical analysis}

Each experiment was repeated three times and data were expressed as means \pm standard deviation. Data processing was carried out by standard methods of mathematical statistics. Homogeneity of the sampling effects was checked using the Student's t-test. The data were subjected to the analysis of variance (ANOVA) using Statistica 10.0 (StatSoft Inc., 2007, USA). Differences between means were considered significant when the confidence interval is smaller than $5 \%$ $(P \leq 0.05)$.

\section{RESULTS AND DISCUSSION}

At the preliminary stage of the study, the compositions of modified gas mixtures for fruit storage were determined, the gas ratio $\left(\mathrm{O}_{2}: \mathrm{N}_{2}: \mathrm{CO}_{2}\right) 3.0: 95.0: 2.0$ and $3.0: 77.0: 2$ 0.0 in $\%$, respectively, for apples and tomatoes. Similar combinations of gases of the modified gas mixture prevented the development of aerobic bacteria (Salmonella, Clostridium Botulinum, Moraxella, and Acinobacter), counteracted the development of mold, reduced the $\mathrm{pH}$ level in the medium of the packaged product, and did not deform or compress the product, which is important when packaging fresh-cut and minimally processed fruits and vegetables.

Samples of apples and tomatoes were examined for microbiological growth during storage, depending on the selected packaging technology (Tables 1-2). In all samples, regardless of the packaging technology, E. coli and other pathogenic bacteria (including L. Monocytogenes) were not detected during the entire study period. After 15 days of storage, apples and tomato fruit treated only with the biopreservative contained at least $40 \%$ less fungi than the untreated samples, while the fruit treated with the biopreservative in combination with MAP had no fungal growth. Apples, processed with the biopreservative and packaged with modified atmosphere, did not contain fungi after 25 days of storage. Fruit packaged without modified atmosphere contained at least $13 \%$ less fungi than samples without treatment. The content of fungi in the untreated tomato samples (control) exceeded the content of fungi in the treated samples packaged with modified atmosphere (over four times more), as well as in the treated fruit samples without MAP (on 84\%).

Packaging of cherry tomatoes in polypropylene or polyethylene bags of low density in a modified gas mixture (5\% $\mathrm{O}_{2}, 5 \% \mathrm{CO}_{2}$ ) increased their shelf life at a temperature of $5^{\circ} \mathrm{C}$ to 25 days. The combination of UV irradiation, low temperatures, and MAP $\left(5.3 \% \mathrm{CO}_{2}+5.5 \% \mathrm{O}_{2}\right)$ allowed improving the antioxidant quality and microbiological safety, and extending the shelf life of cherry tomatoes [Choi et al., 2015]. Irradiation of strawberries and $\mathrm{MAP}\left(\mathrm{CO}_{2}-10 \%: \mathrm{O}_{2}-5 \% ; \mathrm{N}_{2}\right.$ - $85 \%$ ) allowed increasing their storage period at a temperature of $4^{\circ} \mathrm{C}$ to 14 days with the preservation of external quality 
TABLE 1. Changes in fungal growth of packaged apple samples within 25 days of storage.

\begin{tabular}{|c|c|c|c|}
\hline $\begin{array}{l}\text { Duration } \\
\text { of storage } \\
\text { (days) }\end{array}$ & $\begin{array}{c}\text { Penicillium } \\
\text { expansum } \\
(\log \mathrm{CFU} / \mathrm{g})\end{array}$ & $\begin{array}{c}\text { Rhizopus } \\
\text { stolonifer } \\
\text { (log CFU/g) }\end{array}$ & $\begin{array}{c}\text { Botrytis } \\
\text { cinerea } \\
\text { (log CFU/g) }\end{array}$ \\
\hline \multicolumn{4}{|c|}{ Control } \\
\hline 0 & $\mathrm{NF}^{\mathrm{a}}$ & $\mathrm{NF}^{\mathrm{a}}$ & $N^{a}$ \\
\hline 5 & $0.5 \pm 0.0^{\mathrm{a}}$ & $1.0 \pm 0.1^{\mathrm{a}}$ & $1.2 \pm 0.1^{\mathrm{a}}$ \\
\hline 10 & $2.2 \pm 0.1^{\mathrm{a}}$ & $3.4 \pm 0.2^{\mathrm{a}}$ & $3.0 \pm 0.3^{\mathrm{a}}$ \\
\hline 15 & $5.8 \pm 0.3^{\mathrm{a}}$ & $6.5 \pm 0.3^{\mathrm{a}}$ & $5.5 \pm 0.2^{\mathrm{a}}$ \\
\hline 20 & $7.1 \pm 0.4^{\mathrm{a}}$ & $7.6 \pm 0.4^{a}$ & $6.4 \pm 0.3^{a}$ \\
\hline 25 & $9.6 \pm 0.4^{\mathrm{a}}$ & $10.0 \pm 0.4^{\mathrm{a}}$ & $8.8 \pm 0.3^{\mathrm{a}}$ \\
\hline \multicolumn{4}{|c|}{$\mathrm{BIO}$} \\
\hline 0 & $\mathrm{NF}^{\mathrm{b}}$ & $\mathrm{NF}^{\mathrm{b}}$ & $\mathrm{NF}^{\mathrm{b}}$ \\
\hline 5 & $\mathrm{NF}^{\mathrm{b}}$ & $\mathrm{NF}^{\mathrm{b}}$ & $\mathrm{NF}^{\mathrm{b}}$ \\
\hline 10 & $\mathrm{NF}^{\mathrm{b}}$ & $\mathrm{NF}^{b}$ & $\mathrm{NF}^{\mathrm{b}}$ \\
\hline 15 & $4.0 \pm 0.1^{\mathrm{b}}$ & $3.5 \pm 0.1^{\mathrm{b}}$ & $\mathrm{NF}^{\mathrm{b}}$ \\
\hline 20 & $5.8 \pm 0.3^{b}$ & $4.9 \pm 0.3^{\mathrm{b}}$ & $3.6 \pm 0.2^{\mathrm{b}}$ \\
\hline 25 & $8.5 \pm 0.3^{b}$ & $7.0 \pm 0.2^{\mathrm{b}}$ & $4.5 \pm 0.1^{\mathrm{b}}$ \\
\hline \multicolumn{4}{|c|}{$\mathrm{BIO}+\mathrm{MAP} 1$} \\
\hline 0 & $\mathrm{NF}^{\mathrm{c}}$ & $\mathrm{NF}^{\mathrm{c}}$ & $\mathrm{NF}^{\mathrm{c}}$ \\
\hline 5 & $\mathrm{NF}^{\mathrm{c}}$ & $\mathrm{NF}^{\mathrm{c}}$ & $\mathrm{NF}^{\mathrm{c}}$ \\
\hline 10 & $\mathrm{NF}^{\mathrm{c}}$ & $\mathrm{NF}^{\mathrm{c}}$ & $\mathrm{NF}^{\mathrm{c}}$ \\
\hline 15 & $\mathrm{NF}^{\mathrm{c}}$ & $\mathrm{NF}^{\mathrm{c}}$ & $\mathrm{NF}^{\mathrm{c}}$ \\
\hline 20 & $\mathrm{NF}^{\mathrm{c}}$ & $\mathrm{NF}^{\mathrm{c}}$ & $\mathrm{NF}^{\mathrm{c}}$ \\
\hline 25 & $\mathrm{NF}^{\mathrm{c}}$ & $\mathrm{NF}^{\mathrm{c}}$ & $\mathrm{NF}^{\mathrm{c}}$ \\
\hline
\end{tabular}

Control - samples not processed with biopreservative and packaged without modified gas mixture; $\mathrm{BIO}$ - samples treated with biopreservative; $\mathrm{BIO}+\mathrm{MAP} 1$ - samples treated with biopreservative and packaged with a modified gas medium; NF - not found. The data are expressed as mean \pm standard deviation $(n=3)$. Values followed by different letters in a column are significantly different $(P \leq 0.05)$ by LSD post-hoc test.

characteristics [Jouki \& Khazaei, 2014; Fagundes et al., 2015]. The obtained data agree with those already published. Thus, we can state that combining the treatment of fresh vegetables and fruit with a biopreservative, based on bacteriocins of lactic acid or other bacteria, and MAP is safe for humans. In addition, MAP preserves the qualitative characteristics of fruit and vegetable products. The shelf life of these products can be prolonged as well, without using any chemicals.

The results of studying the qualitative characteristics (fruit weight, TSS, $\mathrm{pH}$, firmness, and color) of fruit during storage are presented in Tables 3-4. The tissues structure of apples and tomatoes was not damaged during the experiment. The loss in fruit weight leads to the quality decrease of the product [Briassoulis et al., 2013]. Obviously, during storage, the weight of a fruit decreases, but its intensity is determined by the method of packaging and storage [Khorshidi et al., 2010]. When stored at room temperature, the reduction
TABLE 2. Changes in fungal growth of packaged tomato samples within 25 days of storage.

\begin{tabular}{|c|c|c|c|}
\hline $\begin{array}{l}\begin{array}{l}\text { Duration } \\
\text { of storage } \\
\text { (days) }\end{array} \\
\end{array}$ & $\begin{array}{c}\text { Penicillium } \\
\text { expansum } \\
(\log \mathrm{CFU} / \mathrm{g})\end{array}$ & $\begin{array}{c}\text { Rhizopus } \\
\text { stolonifer } \\
\text { (log CFU/g) }\end{array}$ & $\begin{array}{c}\text { Botrytis } \\
\text { cinerea } \\
(\log \mathrm{CFU} / \mathrm{g})\end{array}$ \\
\hline \multicolumn{4}{|c|}{ Control } \\
\hline 0 & $\mathrm{NF}^{\mathrm{a}}$ & $\mathrm{NF}^{\mathrm{a}}$ & $\mathrm{NF}^{\mathrm{a}}$ \\
\hline 5 & $1.1 \pm 0.1^{\mathrm{a}}$ & $0.8 \pm 0.0^{\mathrm{a}}$ & $1.4 \pm 1.0^{\mathrm{a}}$ \\
\hline 10 & $2.5 \pm 0.2^{\mathrm{a}}$ & $2.6 \pm 0.2^{\mathrm{a}}$ & $2.2 \pm 0.1^{\mathrm{a}}$ \\
\hline 15 & $6.3 \pm 0.3^{\mathrm{a}}$ & $7.0 \pm 0.3^{\mathrm{a}}$ & $5.8 \pm 0.2^{\mathrm{a}}$ \\
\hline 20 & $8.7 \pm 0.5^{\mathrm{a}}$ & $9.2 \pm 0.4^{\mathrm{a}}$ & $7.5 \pm 0.3^{\mathrm{a}}$ \\
\hline 25 & $11.4 \pm 0.5^{\mathrm{a}}$ & $12.3 \pm 0.5^{\mathrm{a}}$ & $9.0 \pm 0.3^{\mathrm{a}}$ \\
\hline \multicolumn{4}{|c|}{$\mathrm{BIO}$} \\
\hline 0 & $\mathrm{NF}^{\mathrm{b}}$ & $\mathrm{NF}^{\mathrm{b}}$ & $\mathrm{NF}^{\mathrm{b}}$ \\
\hline 5 & $\mathrm{NF}^{\mathrm{b}}$ & $\mathrm{NF}^{\mathrm{b}}$ & $0.2 \pm 0.0^{\mathrm{b}}$ \\
\hline 10 & $1.8 \pm 0.1^{\mathrm{b}}$ & $1.5 \pm 0.1^{\mathrm{b}}$ & $1.7 \pm 0.1^{\mathrm{b}}$ \\
\hline 15 & $4.5 \pm 0.1^{b}$ & $3.0 \pm 0.1^{\mathrm{b}}$ & $2.5 \pm 0.1^{\mathrm{b}}$ \\
\hline 20 & $5.0 \pm 0.2^{b}$ & $4.8 \pm 0.2^{\mathrm{b}}$ & $3.8 \pm 0.2^{\mathrm{b}}$ \\
\hline 25 & $5.6 \pm 0.2^{b}$ & $6.0 \pm 0.2^{\mathrm{b}}$ & $4.9 \pm 0.2^{b}$ \\
\hline \multicolumn{4}{|c|}{$\mathrm{BIO}+\mathrm{MAP} 2$} \\
\hline 0 & $\mathrm{NF}^{\mathrm{c}}$ & $N^{c}$ & $\mathrm{NF}^{\mathrm{c}}$ \\
\hline 5 & $\mathrm{NF}^{\mathrm{c}}$ & $\mathrm{NF}^{\mathrm{c}}$ & $\mathrm{NF}^{\mathrm{c}}$ \\
\hline 10 & $\mathrm{NF}^{\mathrm{c}}$ & $\mathrm{NF}^{\mathrm{c}}$ & $\mathrm{NF}^{\mathrm{c}}$ \\
\hline 15 & $\mathrm{NF}^{\mathrm{c}}$ & $\mathrm{NF}^{\mathrm{c}}$ & $\mathrm{NF}^{\mathrm{c}}$ \\
\hline 20 & $\mathrm{NF}^{\mathrm{c}}$ & $\mathrm{NF}^{\mathrm{c}}$ & $\mathrm{NF}^{\mathrm{c}}$ \\
\hline 25 & $1.2 \pm 0.1^{\mathrm{c}}$ & $3.0 \pm 0.1^{\mathrm{c}}$ & $1.8 \pm 0.1^{\mathrm{c}}$ \\
\hline
\end{tabular}

Control - samples not processed with biopreservative and packaged without modified gas mixture; BIO - samples treated with biopreservative; $\mathrm{BIO}+\mathrm{MAP} 2$ - samples treated with biopreservative and packaged with a modified gas medium; NF - not found. The data are expressed as mean \pm standard deviation $(n=3)$. Values followed by different letters in a column are significantly different $(P \leq 0.05)$ by LSD post-hoc test.

in fruit weight is always more pronounced than when stored in refrigeration units. Tomato and apple weight loss was less than $5 \%$ within 25 days of storage, depending on the method of packaging. According to Kader \& Saltveit [2003], about $3-5 \%$ post-harvest weight loss of the product is due to the release of $\mathrm{CO}_{2}$ through the fruit skin. Weight loss of more than $3-5 \%$ usually leads to the loss of freshness.

In the package without modified atmosphere, the weight loss was higher than in the package with modified atmosphere when storing tomatoes and apples, but did not exceed 5\% within 25 days. It is possible that the presence of an antimicrobial coating and a modified gaseous medium led to a decrease in the moisture evaporation rate by reducing the permeability of the peel. However, weight loss of less than $3 \%$ after 25 days of storage is a good indicator for increasing the shelf life of tomatoes and apples in packages with modified atmosphere and an antimicrobial agent. 
TABLE 3. Changes of quality indicators of packaged apple samples within 25 days of storage.

\begin{tabular}{|c|c|c|c|c|c|}
\hline \multirow{2}{*}{$\begin{array}{l}\text { Duration } \\
\text { of storage (days) }\end{array}$} & \multicolumn{5}{|c|}{ Indicators } \\
\hline & Weight (g) & TSS $\left({ }^{\circ}\right.$ Brix $)$ & $\mathrm{pH}$ & Firmness (N) & Hue angle (h) \\
\hline \multicolumn{6}{|c|}{ Control } \\
\hline 0 & $184.2 \pm 9.0^{\mathrm{a}}$ & $12.9 \pm 0.6^{\mathrm{a}}$ & $3.5 \pm 0.2^{\mathrm{a}}$ & $73.6 \pm 3.6^{\mathrm{a}}$ & $78.0 \pm 4.0^{\mathrm{a}}$ \\
\hline 5 & $182.5 \pm 9.1^{\mathrm{a}}$ & $12.9 \pm 0.6^{\mathrm{a}}$ & $3.5 \pm 0.2^{\mathrm{a}}$ & $73.1 \pm 3.6^{\mathrm{a}}$ & $78.0 \pm 4.0^{\mathrm{a}}$ \\
\hline 10 & $180.9 \pm 9.0^{\mathrm{a}}$ & $13.0 \pm 0.7^{\mathrm{a}}$ & $3.5 \pm 0.2^{\mathrm{a}}$ & $73.0 \pm 3.6^{\mathrm{a}}$ & $78.0 \pm 4.0^{\mathrm{a}}$ \\
\hline 15 & $178.2 \pm 8.9^{\mathrm{a}}$ & $13.1 \pm 0.7^{\mathrm{a}}$ & $3.5 \pm 0.2^{\mathrm{a}}$ & $72.9 \pm 3.6^{\mathrm{a}}$ & $78.0 \pm 4.0^{\mathrm{a}}$ \\
\hline 20 & $176.0 \pm 8.9^{\mathrm{a}}$ & $13.3 \pm 0.7^{\mathrm{a}}$ & $3.5 \pm 0.2^{\mathrm{a}}$ & $72.8 \pm 3.6^{\mathrm{a}}$ & $78.0 \pm 4.0^{\mathrm{a}}$ \\
\hline 25 & $175.4 \pm 8.9^{\mathrm{a}}$ & $13.4 \pm 0.7^{\mathrm{a}}$ & $3.4 \pm 0.2^{\mathrm{a}}$ & $72.7 \pm 3.7^{\mathrm{a}}$ & $78.0 \pm 4.0^{\mathrm{a}}$ \\
\hline \multicolumn{6}{|c|}{$\mathrm{BIO}$} \\
\hline 0 & $184.2 \pm 9.0^{\mathrm{a}}$ & $12.9 \pm 0.6^{\mathrm{a}}$ & $3.5 \pm 0.2^{\mathrm{a}}$ & $73.6 \pm 3.6^{\mathrm{b}}$ & $78.0 \pm 4.0^{\mathrm{a}}$ \\
\hline 5 & $182.2 \pm 9.1^{\mathrm{a}}$ & $13.0 \pm 0.7^{\mathrm{a}}$ & $3.5 \pm 0.2^{\mathrm{a}}$ & $73.5 \pm 3.6^{\mathrm{b}}$ & $78.0 \pm 4.0^{\mathrm{a}}$ \\
\hline 10 & $181.5 \pm 9.1^{\mathrm{a}}$ & $13.1 \pm 0.7^{\mathrm{a}}$ & $3.5 \pm 0.2^{\mathrm{a}}$ & $73.5 \pm 3.6^{\mathrm{b}}$ & $78.0 \pm 4.0^{\mathrm{a}}$ \\
\hline 15 & $179.9 \pm 9.0^{\mathrm{a}}$ & $13.1 \pm 0.7^{\mathrm{a}}$ & $3.5 \pm 0.2^{\mathrm{a}}$ & $73.4 \pm 3.6^{\mathrm{b}}$ & $78.0 \pm 4.0^{\mathrm{a}}$ \\
\hline 20 & $176.1 \pm 8.8^{\mathrm{a}}$ & $13.2 \pm 0.7^{\mathrm{a}}$ & $3.5 \pm 0.2^{\mathrm{a}}$ & $73.3 \pm 3.6^{\mathrm{b}}$ & $78.0 \pm 4.0^{\mathrm{a}}$ \\
\hline 25 & $175.6 \pm 9.0^{\mathrm{a}}$ & $13.5 \pm 0.6^{\mathrm{a}}$ & $3.4 \pm 0.2^{\mathrm{a}}$ & $73.3 \pm 3.6^{\mathrm{b}}$ & $78.0 \pm 4.0^{\mathrm{a}}$ \\
\hline \multicolumn{6}{|c|}{$\mathrm{BIO}+\mathrm{MAP} 1$} \\
\hline 0 & $184.2 \pm 9.0^{\mathrm{a}}$ & $12.9 \pm 0.6^{\mathrm{a}}$ & $3.5 \pm 0.2^{\mathrm{a}}$ & $73.6 \pm 3.6^{\mathrm{b}}$ & $78.0 \pm 4.0^{\mathrm{a}}$ \\
\hline 5 & $183.8 \pm 9.2^{\mathrm{a}}$ & $13.0 \pm 0.7^{\mathrm{a}}$ & $3.5 \pm 0.2^{\mathrm{a}}$ & $73.6 \pm 3.6^{b}$ & $78.0 \pm 4.0^{\mathrm{a}}$ \\
\hline 10 & $181.3 \pm 9.1^{\mathrm{a}}$ & $13.0 \pm 0.7^{\mathrm{a}}$ & $3.5 \pm 0.2^{\mathrm{a}}$ & $73.6 \pm 3.6^{b}$ & $78.0 \pm 4.0^{\mathrm{a}}$ \\
\hline 15 & $179.4 \pm 9.0^{\mathrm{a}}$ & $13.2 \pm 0.7^{\mathrm{a}}$ & $3.5 \pm 0.2^{\mathrm{a}}$ & $73.5 \pm 3.6^{b}$ & $78.0 \pm 4.0^{\mathrm{a}}$ \\
\hline 20 & $179.0 \pm 9.0^{\mathrm{a}}$ & $13.3 \pm 0.7^{\mathrm{a}}$ & $3.5 \pm 0.2^{\mathrm{a}}$ & $73.5 \pm 3.6^{\mathrm{b}}$ & $78.0 \pm 4.0^{\mathrm{a}}$ \\
\hline 25 & $178.8 \pm 8.9^{\mathrm{a}}$ & $13.5 \pm 0.6^{\mathrm{a}}$ & $3.3 \pm 0.2^{\mathrm{a}}$ & $73.4 \pm 3.7^{\mathrm{b}}$ & $78.0 \pm 4.0^{\mathrm{a}}$ \\
\hline
\end{tabular}

Control - samples not processed with biopreservative and packaged without modified gas mixture; BIO - samples treated with biopreservative; BIO + MAP1 - samples treated with biopreservative and packaged with a modified gas medium. The data are expressed as mean $\pm \operatorname{standard~deviation~}(n=3)$. Values followed by the same letter in a column do not differ significantly $(P>0.05)$ by LSD post-hoc test.

During the storage period under consideration, TSS of tomato fruit decreased up to $4 \%$, depending on the packaging method. Changes in the TSS content of apples were practically not observed $(P=0.982)$. Wright \& Kader [1997] and Erkan et al. [2004] reported that after nine months of storage there was a slight loss of TSS, explaining this either by the ratio of gases in MAP, or by the hydrolysis of polysaccharides to monosaccharides [Visser et al., 1968].

During the storage, the $\mathrm{pH}$-value of tomatoes increased and the $\mathrm{pH}$-value of apples decreased. In this case, the type of packaging did not affect the taste of fruit. It is known that taste sensations depend not only on the concentration of acids and sugars, but also on their ratio. Fruits can have a more acidic taste, not from a high content of organic acids, but from low sugar, and vice versa. It seems that after 25 days of storage, the content of sugars and the concentration of organic acids used for product's respiration was increased, leading to metabolic changes. The same results were obtained in the study by Tumwesigye et al. [2017]. The sugar content at the end of the shelf life decreased, and the $\mathrm{pH}$ value increased slightly over time as the concentration of organic acids was declining with maturity due to the utilization of malic acid as a substrate for respiration. The change was also attributed to the metabolic changes and water loss in cherry tomatoes. With those storage and package conditions, the fruit had fully met the necessary tomato market requirements.

Fruit firmness is one of the important quality parameters, both for apples and tomatoes. The loss of firmness in apples is noticeable with prolonged storage or with short-term storage of already overripe fruit, and is closely associated with a decrease in water content and metabolic changes [García et al., 1998]. Firmness of tomatoes decreases more quickly than that of apples. After 25 days of storage, the firmness of tomatoes was almost halved, and the apples remained virtually unchanged $(P=0.846)$.

There was a slight change in the intensity of the color of tomatoes, which can be explained by the ripening of these fruit (hydroxylation of carotenoids and synthesis of xanthophylls in them) [Gross, 1991]. Changes in the color of apples were not observed within 25 days of storage $(P=0.999)$. A similar 
TABLE 4. Changes of quality indicators of packaged tomato samples within 25 days of storage.

\begin{tabular}{|c|c|c|c|c|c|}
\hline \multirow{2}{*}{$\begin{array}{l}\text { Duration } \\
\text { of storage (days) }\end{array}$} & \multicolumn{5}{|c|}{ Indicators } \\
\hline & Weight (g) & TSS ( ${ }^{\circ}$ Brix $)$ & $\mathrm{pH}$ & Firmness $(\mathrm{N})$ & Hue angle (h) \\
\hline \multicolumn{6}{|c|}{ Control } \\
\hline 0 & $158.3 \pm 8.0^{\mathrm{a}}$ & $5.7 \pm 0.3^{\mathrm{a}}$ & $3.7 \pm 0.2^{\mathrm{a}}$ & $2.6 \pm 0.1^{\mathrm{a}}$ & $23.1 \pm 1.2^{\mathrm{a}}$ \\
\hline 5 & $156.7 \pm 7.8^{\mathrm{a}}$ & $5.7 \pm 0.3^{\mathrm{a}}$ & $3.7 \pm 0.2^{\mathrm{a}}$ & $2.4 \pm 0.1^{\mathrm{a}}$ & $23.6 \pm 1.2^{\mathrm{a}}$ \\
\hline 10 & $154.8 \pm 7.7^{\mathrm{a}}$ & $5.6 \pm 0.3^{\mathrm{a}}$ & $3.7 \pm 0.2^{\mathrm{a}}$ & $2.2 \pm 0.1^{\mathrm{a}}$ & $23.9 \pm 1.2^{\mathrm{a}}$ \\
\hline 15 & $153.0 \pm 7.7^{\mathrm{a}}$ & $5.6 \pm 0.3^{\mathrm{a}}$ & $3.7 \pm 0.2^{\mathrm{a}}$ & $2.0 \pm 0.1^{\mathrm{a}}$ & $24.8 \pm 1.2^{\mathrm{a}}$ \\
\hline 20 & $152.4 \pm 7.6^{\mathrm{a}}$ & $5.5 \pm 0.3^{\mathrm{a}}$ & $3.8 \pm 0.2^{\mathrm{a}}$ & $1.7 \pm 0.1^{\mathrm{a}}$ & $25.1 \pm 1.3^{\mathrm{a}}$ \\
\hline 25 & $151.3 \pm 7.8^{\mathrm{a}}$ & $5.4 \pm 0.3^{\mathrm{a}}$ & $3.8 \pm 0.2^{\mathrm{a}}$ & $1.3 \pm 0.1^{\mathrm{a}}$ & $25.3 \pm 1.3^{\mathrm{a}}$ \\
\hline \multicolumn{6}{|c|}{$\mathrm{BIO}$} \\
\hline 0 & $158.3 \pm 8.0^{\mathrm{ab}}$ & $5.7 \pm 0.3^{\mathrm{a}}$ & $3.7 \pm 0.2^{\mathrm{a}}$ & $2.6 \pm 0.1^{\mathrm{a}}$ & $23.1 \pm 1.2^{\mathrm{a}}$ \\
\hline 5 & $155.9 \pm 7.8^{\mathrm{ab}}$ & $5.7 \pm 0.3^{\mathrm{a}}$ & $3.7 \pm 0.2^{\mathrm{a}}$ & $2.5 \pm 0.1^{\mathrm{a}}$ & $23.5 \pm 1.2^{\mathrm{a}}$ \\
\hline 10 & $155.0 \pm 7.7^{\mathrm{ab}}$ & $5.7 \pm 0.3^{\mathrm{a}}$ & $3.7 \pm 0.2^{\mathrm{a}}$ & $2.1 \pm 0.1^{\mathrm{a}}$ & $24.2 \pm 1.2^{\mathrm{a}}$ \\
\hline 15 & $153.6 \pm 7.7^{\mathrm{ab}}$ & $5.6 \pm 0.3^{\mathrm{a}}$ & $3.8 \pm 0.2^{\mathrm{a}}$ & $1.6 \pm 0.1^{\mathrm{a}}$ & $25.1 \pm 1.3^{\mathrm{a}}$ \\
\hline 20 & $152.5 \pm 7.6^{\mathrm{ab}}$ & $5.6 \pm 0.3^{\mathrm{a}}$ & $3.8 \pm 0.2^{\mathrm{a}}$ & $1.4 \pm 0.1^{\mathrm{a}}$ & $25.2 \pm 1.3^{\mathrm{a}}$ \\
\hline 25 & $151.7 \pm 7.8^{\mathrm{ab}}$ & $5.5 \pm 0.3^{\mathrm{a}}$ & $3.8 \pm 0.2^{\mathrm{a}}$ & $1.3 \pm 0.1^{\mathrm{a}}$ & $25.3 \pm 1.2^{\mathrm{a}}$ \\
\hline \multicolumn{6}{|c|}{$\mathrm{BIO}+\mathrm{MAP} 2$} \\
\hline 0 & $158.3 \pm 8.0^{\mathrm{b}}$ & $5.7 \pm 0.3^{\mathrm{a}}$ & $3.7 \pm 0.2^{\mathrm{a}}$ & $2.6 \pm 0.1^{\mathrm{a}}$ & $23.1 \pm 1.2^{\mathrm{a}}$ \\
\hline 5 & $157.9 \pm 7.9^{\mathrm{b}}$ & $5.7 \pm 0.3^{\mathrm{a}}$ & $3.7 \pm 0.2^{\mathrm{a}}$ & $2.0 \pm 0.1^{\mathrm{a}}$ & $23.4 \pm 1.2^{\mathrm{a}}$ \\
\hline 10 & $157.5 \pm 7.8^{\mathrm{b}}$ & $5.7 \pm 0.3^{\mathrm{a}}$ & $3.7 \pm 0.2^{\mathrm{a}}$ & $1.8 \pm 0.1^{\mathrm{a}}$ & $23.8 \pm 1.2^{\mathrm{a}}$ \\
\hline 15 & $157.0 \pm 7.8^{\mathrm{b}}$ & $5.6 \pm 0.3^{\mathrm{a}}$ & $3.8 \pm 0.1^{\mathrm{a}}$ & $1.7 \pm 0.1^{\mathrm{a}}$ & $24.6 \pm 1.2^{\mathrm{a}}$ \\
\hline 20 & $156.4 \pm 7.8^{\mathrm{b}}$ & $5.6 \pm 0.3^{\mathrm{a}}$ & $3.8 \pm 0.1^{\mathrm{a}}$ & $1.5 \pm 0.1^{\mathrm{a}}$ & $25.0 \pm 1.2^{\mathrm{a}}$ \\
\hline 25 & $156.0 \pm 7.9^{\mathrm{b}}$ & $5.5 \pm 0.3^{\mathrm{a}}$ & $3.8 \pm 0.1^{\mathrm{a}}$ & $1.4 \pm 0.1^{\mathrm{a}}$ & $25.2 \pm 1.2^{\mathrm{a}}$ \\
\hline
\end{tabular}

Control - samples not processed with biopreservative and packaged without modified gas mixture; BIO - samples treated with biopreservative; BIO + MAP2 - samples treated with biopreservative and packaged with a modified gas medium. The data are expressed as mean \pm standard deviation $(n=3)$. Values followed by the same letter in a column do not differ significantly $(P>0.05)$ by LSD post-hoc test.

result was reported for apples and pears [Bessemans et al., 2016; Mditshwa et al., 2017].

The three preservation methods had a significantly different effect on fungal growth. The ratio of the quality characteristic values for fruit without a biopreservative and with a preservative is comparable for both tomatoes and apples for 25 days of storage. The best results were observed in fruit for which a combined treatment method was used (BIO+MAP).

\section{CONCLUSIONS}

The need to ensure food security requires researchers to develop technologies for preserving food without deteriorating the quality characteristics and, preferably, at the lowest costs. The efficiency of the combined preservation technology (for apples and tomatoes) using a biopreservative and MAP was studied. The results of microbiological indicators of packaged fruit were obtained immediately after processing and packaging, and also after $5,10,15,20$, and 25 days of storage at a temperature of $4^{\circ} \mathrm{C}$. Samples of fruit treated with biopreser- vatives and packaged with modified atmosphere produced the best microbiological results after 25 days of storage. Qualitative characteristics of packaged fruit remained within the permissible freshness for 25 days of storage. Undoubtedly, the physicochemical characteristics of the fruit we examined are determined by the variety, geographic and climatic conditions of growth, and even by the degree of maturity of the harvested fruit. Therefore, we assume that for other samples of tomatoes and apples, the differences can be more significant for the considered packaging and storage conditions. However, the technology of preserving vegetables and fruit with a biopreservative in combination with a MAP confirms its potential.

\section{RESEARCH FUNDING}

The work was carried out with partial financial support of the international financial initiative Eurotransbio [12467r/23886], Russian Foundation for Basic Research [18-016-00063], and Council of the President of the Russian Federation on grants [SP-1374.2018.4]. 


\section{CONFLICTS OF INTEREST}

Authors declare that there is no conflict of interest.

\section{REFERENCES}

1. Allende, A., Artés, F. (2003). Combined ultraviolet-C and modified atmosphere packaging treatments for reducing microbial growth of fresh processed lettuce. LWT-Food Science and Technology, 36(8), 779-786.

2. Alvarez, M.V., Moreira, M. del R., Roura, S.I., Ayala-Zavala, J.F., González-Aguilar, G.A. (2015). Using natural antimicrobials to enhance the safety and quality of fresh and processed fruits and vegetables: Types of antimicrobials. In M. Taylor, (ed.), Handbook of Natural Antimicrobials for Food Safety and Quality. Elsevier Inc., Woodhead Publishing, Cambridge, UK, pp. 287-313 .

3. Argyri, A.A., Nisiotou, A.A., Pramateftaki, P., Doulgeraki, A.I., Panagou, E.Z., Tassou, C.C. (2015). Preservation of green table olives fermented with lactic acid bacteria with probiotic potential under modified atmosphere packaging. LWT - Food Science and Technology, 62(1), 783-790.

4. Ayala-Silva, T., Schnell, R.J., Meerow, A.W., Winterstein, M., Cervantes, C., Brown, J.S. (2005). Determination of color and fruit traits of half-sib families of mango (Mangifera indica L.). Proceedings of the Florida State Horticultural Society, 118, 253-257.

5. Bessemans, N., Verboven, P., Verlinden, B., Nicolaï, B. (2016). A novel type of dynamic controlled atmosphere storage based on the respiratory quotient (RQ-DCA). Postharvest Biology and Technology, 115, 91-102.

6. Briassoulis, D., Mistriotis, A., Giannoulis, A., Giannopoulos, D. (2013). Optimized PLA-based EMAP systems for horticultural produce designed to regulate the targeted in package atmosphere. Industrial Crops and Products, 48, 68-80.

7. Burke, D.G., Cotter, P.D., Ross, R.P., Hill, C. (2013). Microbial production of bacteriocins for use in foods. In B. McNeil, D. Archer, I. Giavasis, L. Harvey, (eds.), Microbial Production of Food Ingredients, Enzymes and Nutraceuticals, Elsevier Inc., Woodhead Publishing, Cambridge, UK, pp. 353-384.

8. Buzby, J.C., Hyman, J. (2012). Total and per capita value of food loss in the United States. Food Policy, 37(5), 561-570.

9. Cavicchioli, V.Q., Camargo, A.C., Todorov, S.D., Nero, L.A. (2017). Novel bacteriocinogenic Enterococcus hirae and Pediococcus pentosaceus strains with antilisterial activity isolated from Brazilian artisanal cheese. Journal of Dairy Science, 100(4), 2526-2535.

10. Choi, D.S., Park, S.H., Choi, S.R., Kim, J.S., Chun, H.H. (2015). The combined effects of ultraviolet- $\mathrm{C}$ irradiation and modified atmosphere packaging for inactivating Salmonella enterica serovar Typhimurium and extending the shelf life of cherry tomatoes during cold storage. Food Packaging and Shelf Life, 3, 19-30.

11. Colgecen, I., Aday, M.S. (2015). The efficacy of the combined use of chlorine dioxide and passive modified atmosphere packaging on sweet cherry quality. Postharvest Biology and Technology, 109, 10-19.

12. De Laurentiis, V., Corrado, S., Sala, S. (2018). Quantifying household waste of fresh fruit and vegetables in the EU. Waste Management, 77, 238-251.
13. Dyshlyuk, L., Babich, O., Prosekov, A., Ivanova, S., Pavsky, V., Yang, Y. (2017). In vivo study of medical and biological properties of functional bakery products with the addition of pumpkin flour. Bioactive Carbohydrates and Dietary Fibre, 12, 20-24.

14. Erkan, M., Gübbük, P.H., Karasahln, I. (2004). Effectts of controlled atmosphere storage on scald development and postharvest physiology of Granny Smith apples. Turkish Journal of Agriculture and Forestry, 28(1), 43-48.

15. Fagundes, C., Moraes, K., Pérez-Gago, M.B., Palou, L., Maraschin, M., Monteiro, A.R. (2015). Effect of active modified atmosphere and cold storage on the postharvest quality of cherry tomatoes. Postharvest Biology and Technology, 109, 73-81.

16. FAO (2011). Global food losses and food waste - Extent, causes and prevention. Rome, Italy.

17. García, B.S.A., Nunes, N.J., Silva, C.S. (1998). Effect of different pre-freezing treatments on the quality of frozen strawberries variety Chandler. Ciencia Tecnologia Alimentos, 18, 82-86.

18. Gross, J. (1991). Pigments in Vegetables-Chlorophylls and Carotenoids. Van Nostrand Reinhold, New York, USA.

19. Ho, V.T.T., Lo, R., Bansal, N., Turner, M. (2018). Characterisation of Lactococcus lactis isolates from herbs, fruits and vegetables for use as biopreservatives against Listeria monocytogenes in cheese. Food Control, 85, 472-483.

20. HunterLab, (2008). Hunter L, a, b colour scale. Applications Note, 8(9), 1-4.

21. Hussein, Z., Caleb, O.J., Opara, U.L. (2015). Perforation-mediated modified atmosphere packaging of fresh and minimally processed produce - A review. Food Packaging and Shelf Life, 6, 7-20.

22. Jaeger, 1.R., Machín, L., Aschemann-Witzel, J., Antúnez, L., Harker, F.R., Ares, G. (2018). Buy, eat or discard? A case study with apples to explore fruit quality perception and food waste. Food Quality and Preference, 69, 10-20.

23. Javanmardi, J., Kubota, C. (2006). Variation of lycopene, antioxidant activity, total soluble solids and weight loss of tomato during postharvest storage. Postharvest Biology and Technology, $41(2), 151-155$.

24. Jouki, M., Khazaei, N. (2014). Effect of low-dose gamma radiation and active equilibrium modified atmosphere packaging on shelf life extension of fresh strawberry fruits. Food Packaging and Shelf Life, 1(1), 49-55.

25. Kader, A.A., Saltveit, M. (2003). Atmosphere modification. In J.A. Bartz, J.K. Brecht, (eds.), Postharvest Physiology and Pathology of Vegetables, Marcel Dekker Inc, New York, USA, pp. 229-246.

26. Khorshidi, J., Tabatabaei, M.F., Ahmadi, F.M. (2010). Storage temperature effects on the postharvest quality of apple (Malus domestica Borkh. cv. "Red Delicious"). New York Science Journal, 3(3), 67-70.

27. Leite, J.A., Tulini, F.L., dos Reis-Teixeira, F.B., Rabinovitch, L., Chaves, J.Q., Rosa, N.G., Cabral, H., De Martinis, E.C.P. (2016). Bacteriocin-like inhibitory substances (BLIS) produced by Bacillus cereus: Preliminary characterization and application of partially purified extract containing BLIS for inhibiting Listeria monocytogenes in pineapple pulp. LWT - Food Science and Technology, 72, 261-266.

28. Leroi, F., Cornet, J., Chevalier, F., Cardinal, M., Coeuretc, G., Chaillouc, S., Joffraud, J.-J. (2015). Selection of bioprotective cultures for preventing cold-smoked salmon spoilage. International Journal of Food Microbiology, 213, 79-87. 
29. Ma, L., Zhang, M., Bhandari, B., Gao, Z. (2017). Recent developments in novel shelf life extension technologies of fresh-cut fruits and vegetables. Trends in Food Science \& Technology, 64, 23-38.

30. Mditshwa, A., Fawole, O.A., Vries, F., van der Merwe, K., Crouch, E., Opara, U.L. (2017). Minimum exposure period for dynamic controlled atmospheres to control superficial scald in 'Granny Smith' apples for long distance supply chains. Postharvest Biology and Technology, 127, 27-34.

31. Molloy, E.M., Hill, C., Cotter, P.D., Ross, R.P. (2011). Bacteriocins. In J.W. Fuquay, P.F. Fox, P.L.H. McSweeney, (eds.), Encyclopedia of Dairy Sciences, 2nd edn., Elsevier Inc., Academic Press, London, UK, pp. 420-429.

32. Nes, I.F., Brede, D.A., Holo, H. (2006). The nonlantibiotic heatstable bacteriocins in Gram-positive bacteria. In A.J. Kastin, (ed.), Handbook of Biologically Active Peptides. Elsevier Inc., Academic Press, Boston, USA, pp. 107-114.

33. O'Bryan, C.A., Crandall, P.G., Ricke, S.C., Ndahetuye, J.B. (2015). Lactic acid bacteria (LAB) as antimicrobials in food products: Types and mechanisms of action. In M. Taylor, (ed.), Handbook of Natural Antimicrobials for Food Safety and Quality, Elsevier Inc., Woodhead Publishing, Cambridge, UK, pp. 117-136.

34. Oliveira, M., Abadias, M., Usall, J., Torres, R., Teixidó, N., Viñas, I. (2015). Application of modified atmosphere packaging as a safety approach to fresh-cut fruits and vegetables. Trends in Food Science \& Technology, 46(1), 13-26.

35. Paskeviciute, E., Zudyte, B., Luksiene, Z. (2018). Towards better microbial safety of fresh produce: Chlorophyllin-based photosensitization for microbial control of foodborne pathogens on cherry tomatoes. Journal of Photochemistry and Photobiology B: Biology, 182, 130-136.

36. Prosekov, A.Y., Ivanova, S.A. (2018). Food security: The challenge of the present. Geoforum, 91, 73-77.

37. Putnik, P., Roohinejad, S., Greiner, R., Granato, D., Bekhit, A.E. - D.A., Kovačević, D.B. (2017). Prediction and modeling of mi- crobial growth in minimally processed fresh-cut apples packaged in a modified atmosphere: A review. Food Control, 80, 411-419.

38. Sanger, F., Nicklen, S., Coulson, A.R. (1977). DNA sequencing with chain-terminating inhibitors. Proceedings of the National Academy of Sciences of the United States of America, 74(12), 5463-5467.

39. Settanni, L., Corsetti, A. (2008). Application of bacteriocins in vegetable food biopreservation. International Journal of Food Microbiology, 121(2), 123-138.

40. Tumwesigye, K.S., Sousa, A.R., Oliveira, J.C., Sousa-Gallagher, M.J. (2017). Evaluation of novel bitter cassava film for equilibrium modified atmosphere packaging of cherry tomatoes. Food Packaging and Shelf Life, 13, 1-14.

41. Visser, T., Schaap, A.A., de Vries, D.P. (1968). Acidity and sweetness in apple and pear. Euphytica, 17(2), 153-167.

42. Wang, Y., Bai, J., Long, L.E. (2015). Quality and physiological responses of two late-season sweet cherry cultivars 'Lapins' and 'Skeena' to modified atmosphere packaging (MAP) during simulated long distance ocean shipping. Postharvest Biology and Technology, 110, 1-8.

43. Watson R.R., Preedy V.R. (2016). Fruits, Vegetables, and Herbs. Bioactive Foods in Health Promotion. Academic Press, Elsevier Inc., Oxford, UK.

44. Wright, K.P., Kader, A.A. (1997). Effect of controlled atmosphere storage on the quality and carotenoid content of sliced persimmons and peaches. Postharvest Biology and Technology, 10(1), 89-97.

45. Zimina, M.I., Sukhih, S.A., Babich, O.O., Noskova, S.Yu., Abrashina, A.A., Prosekov, A.Yu. (2016). Investigating antibiotic activity of the genus Bacillus strains and properties of their bacteriocins in order to develop next-generation pharmaceuticals. Foods and Raw Materials, 4(2), 92-100.

Submitted: 18 February 2019. Revised: 25 April and 21 June 2019. Accepted: 9 July 2019. Published on-line: 21 August 2019. 